\title{
On the Wall Paintings Discovered in the Churches of Raunds and Slapton, Northamptonshire
}

\section{J. G. Waller}

To cite this article: J. G. Waller (1877) On the Wall Paintings Discovered in the Churches of Raunds and Slapton, Northamptonshire, Archaeological Journal, 34:1, 219-241, DOI: 10.1080/00665983.1877.10851779

To link to this article: http://dx.doi.org/10.1080/00665983.1877.10851779

$$
\text { 册Published online: } 14 \text { Jul } 2014 .
$$

Submit your article to this journal $\lceil\pi$

Q View related articles $₫$ 
ON THE WALL PAINTINGS DISCOVERED IN THE CHURCHES OF RAUNDS AND SLAPTON, NORTHAMPTONSHIRE.

BY J. G. WALLER.

During the autumns of 1875 and 1876 , I paid visits to the church of Slapton, a small village four miles from Towcester, and to that of Raunds, a few miles from Higham Ferrers, both in the county of Northampton. And it is but right to state, that, in both places, I was the guest of the incumbent, with much kindly hospitality. The church of Raunds has lately been restored by Sir Gilbert Scott, and it was through him that I first became acquainted with the discovery of the extraordinary series of paintings in that church. The paintings of Slapton were discovered by the exertions of the late rector and his lady, Mr. and Mrs. Edman, the latter herself having worked in removing the whitewash.

As time after time, these discoveries are made, it is found, that there is a recurrence of the same subject, therefore to avoid a tedious repetition of description, it is now necessary to classify and to generalize, as well as to allude to the principles, which governed the decoration of our churches during the middle ages. A most useful list of the paintings discovered and recorded has been drawn up under the editorial care of our friend Mr. Soden Smith, and published by the authorities of South Kensington Museum. This list I hold to be valuable in more ways than one, and I consider it must be appealed to by those, who, in future, would study the religious teaching of our ancestors. Briefly let me state, one fact, that subjects from the Bible are rare, and one of the most so is that of the "Last Supper." Instead of illustrating the doctrine of the Eucharist by that, it is preferred to do so by an illustration of the story of St. Gregory's Mass, and this is significant, because it enforces 
the doctrine of transubstantiation. The subjects, mostly found, are taken from legends of saints, and from a class to which we must give the name of moralities. Some of the legends of the saints we must look upon as parables or apologues, and, as such, they have in them much beautiful teaching. Turn them into real histories and you degrade them. If we would comprehend these paintings in the spirit in which they were intended, which in all justice to our forefathers we ought to do, we must never forget what the ecclesiastical writers say of them from the eighth to the fifteenth century, viz., that they are for instruction, for the use of those who cannot read-in fact, the "Book of the ignorant." Any criticism which does not recognise this is unsound and unjust.

Now, of all subjects, St. Christopher is the most commonly found, and is always placed where it can be most readily seen by the worshipper on entering the church, usually, therefore on the north wall. The next most in favour in England was St. George, our patron saint, generally placed on the south wall, often opposite to that of St. Christopher. The legends of both these saints are typical. Both are unquestionably apologues and nothing more. The story of St. Christopher is fully illustrated in an article of mine, published in the collections of the Surrey Archæological. Society,' and to that I must refer for full details.

Among the female saints, the most popular was St. Katharine of Alexandria, and her legend is of frequent illustration.

Of the so-called moralities, there are two, which are mostly found. One is "Soul weighing," the history of which carries us back into the remotest antiquity. Then comes that of "The three Kings dead and the three Kings living," which subject has been fully illustrated by myself in an Article on the Paintings in Battell Church, Sussex, ${ }^{2}$ and also in one by our late friend, Albert Way, in the Journal of this Society. But of this no example, yet discovered, can compare in importance with that at Raunds. Not only is it finer for the art it displays, but its size is grand and imposing, the figures being much beyond the

1 Vol. iii.

2 Journal of British Archrological Association, Vol. ii, 152. 


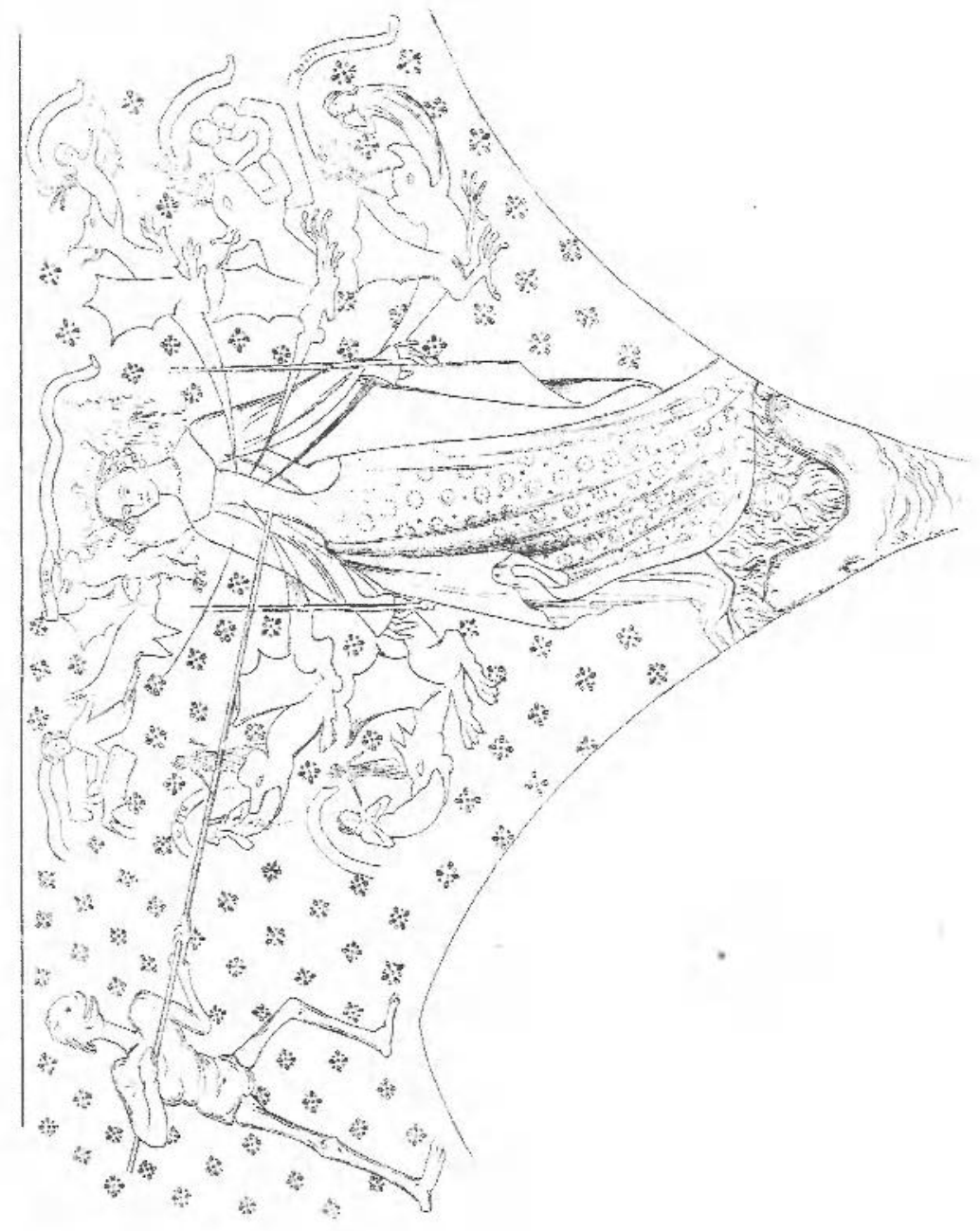


size of life. It is on the north wall of the nave, filling up spaces between the spandrils of the arches. A figure of St. Christopher separates it from the symbolic representation of the "Seven Deadly Sins," and altogether it makes the most complete and effective decoration, yet discovered in any of our medixval churches. The whole of this series, excepting the figure of St. Christopher, is dedicated to the exemplification of the sin of pride, and instability of all worldly things, with the moral that all ends in death. I will begin my description with the painting of the "Seven Deadly Sins." (Vide Plate I.)

It represents a female in rich attire having the long flowing garments of the fifteenth century. A closely fitting corse is at her waist, worn over a richly embroidered gown, and she wears an ample mantle lined with ermine. She is crowned, and holds a sceptre in each hand. Her face has somewhat of a scornful look, the eyes looking half shut: her neck, with a necklace around it, is bare, as well as her bosom. Beneath her is the yawning mouth of a monster, signifying Hell, out of which flames are issuing, and in the midst is a figure representing a soul in torment. At her head, on each side, is a demon. From her body issue six demoniac forms winged, each vomiting forth figures, illustrative of each sin; and these are accompanied by another figure, a shade, which seems to point the moral. Over the head of the principal figure is a scroll; some few letters remaining suggest, that it may have been "Imago Superbiæ et Inanis Gloriæ." Over each of the groups are other scrolls, on which has been written the name of the sin symbolised. Then, at her right hand, is a hideous cadaverous figure of Death, holding a lance in knightly fashion, with which he pierces the woman's side.

This composition is intended to illustrate the sin of Pride, as the mother of all the other sins, and the moral that all ends in death and punishment hereafter. That this view is not based on mere conjecture, I shall now proceed to show, and to give a history, as far as possible, of the growth of the ideas embodied, as far as I can trace them in the Christian Church, and particularly in mediæval theology.

First, let me direct attention to the writings of 
the monk Cæsarius, ${ }^{\text {T }}$ wo lived in the twelfth and thir. teenth century, to whom I have often referred. In his dialogue on "Temptation," is a chapter entitled "Pride and her Six Daughters."

In the preceding one he says "Seven are the principal vices springing from one virulent root, that is to say, Pride, from which almost all temptations proceed. The first vice of Pride succeeding to it is "Empty Glory." The second is "Anger;" third, "Envy;" fourth, "Sloth;" fifth, "Avarice;" sixth, "Gluttony" (Gula vel Gastrimargia) ; seventh, "Luxury." He then classes these. $\mathrm{He}$ calls some spiritual, as "Empty Glory," "Anger," and "Envy ;" others corporal, as "Gluttony" and "Luxury ;" some mixed, as "Sloth" and "Avarice." He proceeds to say, Lucifer, ejected from Heaven on account of Pride, diffused himself in the human heart, darkened by mortal sins; and, that the sins were designated by the seven devils ejected from Mary Magdalene. He then minutely defines "Pride" as being of two kinás -one within, as in elation of the heart; the other without, as in works of ostentation. He then defines "Anger," quoting many passages of Scripture. "Anger," he says, " is a fire." "Envy," he continues, "is born of anger; " indeed, an inveterate anger, and is a hatred of another's "felicity. This vice makes a devil of an angel, and was the " cause of man being ejected from Paradise." The next vice, "Sloth" (Accidia) he states to be much too importunate to religious men. The Novice asks, "What is the meaning of Accidia?" it having a somewhat barbarous sound. The question is interesting, for our Monk is a scholar, and fond of quoting the classics. He explains the word as being "quasi acidia," rendering spiritual works acid and insipid, as malice, rancour, pusillanimity, desperation, a torpor concerning the commandments, a wandering of the mind about unlawful things. We now come to "Avarice," which he calls an insatiable and immoderate appetite of having all things, and he quotes the Apostle, "The root of all evils is Avarice." "The sixth vice is "Gluttony" (Gula), which he styles the

1 Dialogus Miraculorum. Cæsarius was a monk of the Cistercian Order of the Monastery of Heisterbach, near
Konigswinter on the Rhine.

"Timothy vi, 10: "Love of money," in our Version. 
immoderate cause and appetite of eating and drinking. Last and seventh, "Luxury" (Luxuria), the which he minutely describes, and which in mediæval theology signifies illicit affections.

Having thus given the theology, I will now proceed to describe the emblematical figures in agreement with it. It will be observed that these, which represent the six daughters of Pride, are arranged on each side the principal figure. On her right, first comes "Avarice," and unfortunately some details here are indistinct; but the demon seems to issue from the head, as possibly indicating, that it was a vice peculiar to the mind. The figure also appears to be holding, what must be intended to represent, sacks or purses of money, but this is somewhat defaced. Next, beneath this, is "Ira" (Anger), and here the figure from the demon's mouth exhibits drops of blood issuing from the breast; and another figure, like a shade or shadow, stands by pointing at the wound, as probably showing the dangerous effects of Anger. Beneath this comes "Invidia" (Envy), tearing her breast, as it appears,-- the shade again stands by pointing.

We now pass to those on the left side, which show the vices mostly corporal. First is "Gula," in which the figure has lost its distinctive emblem, and the shade seems to be an animal, ' but is too defaced to speak with certainty. The next is "Luxuria," shown in a most unmistakable manner : lastly "Accidia;" here the figure seems as if wearily stretching, and the shade, apparently, quickly moving towards it with uplifted switch.

We must not for one moment suppose that in this curious and interesting composition, we get the work of an individual mind. It is the result of a series of developments, doubtless handed down from very early times. Though by far the most complete and the finest of the various illustrations of the "Seven Deadly Sins," with which we are acquainted, it will be well to make a comparison with others. One discovered a few years ago at Wisborough Green, in Sussex, gave a large nude female figure with a series of winged demons or dragons issuing from the different parts of the body, in which each sin is supposed to reside, or to be affected by. In this we get

1 The emblematical animal usually given to Gula is a hog.

VOL. $X X X I V$. 
another version but by no means so complete nor so full of thought as that at Raunds. On a screen at Catfield, in Norfolk, remain representations of three of the deadly sins, viz., Pride, a figure with a mirror and comb; Anger, with two knives in the breast, from which issue bloody drops; and Avarice, holding out two money bags.' Each issue from a yawning mouth. ${ }^{2}$ At Ingatestone, in Essex, the "Seven Deadly Sins" are represented in the form of a wheel, the subjects being between the spokes. Pride is a lady seated, attiring by the assistance of a maid. Anger is a fight between two persons. Luxury, a man kissing a girl. Sloth, a man in bed, seemingly in a monastery. ${ }^{3}$ Avarice, a miser with his money. Gluttony, men and women drinking in a cellar. Envy, scene before a justice, witnesses swearing falsely. In the centre is Hell's mouth.

In the early ages of Christianity there was no such classification as the "Seven Deadly Sins." This belongs to a later time, and was possibly due to the spread of monasticism. Amongst the poems of the poet Prudentius, who lived in the fourth century, and was the contemporary of St. Ambrose, is one entituled "Psychomachia," which arrays the Virtues in a struggle with the Vices. It is too classical in its allusions to help us much in the history of our subject; but it serves to point out the changes, which a later time had developed. Here are Superbia, Ira, and Avaritia. There is also Luxuria, but it is as we understand the word now; luxury as expressed in superfluity and excess in attire and mode of life. There is also "Libido," which of course has the meaning given in Monkish Latin to Luxuria; and lastly "Discordia," which, if expressed at all in the later time, must be found in the term "Invidia." The most illustrative passages are those relating to "Avaritia," whom he describes as, not content only to collect fragments of gold into heaps and to fill her ample bosom, but delights to stuff the base lucre into bags.

"Nec sufficit amplos

Implevisse sinus, juvat infarcire crumenis, Turpe lucrum."

In a curious collection of mediæval sermons of the fifteenth century, entituled "Dormi Secure," there are

1 This confirms the previous suggestion.

2 Vide engravings in Norfolk Archæ-

3 See the passages quoted from ology. 
often allusions to allegorical figures and their mode of treatment by the Romans. I am not inclined to think these are references to classic times, exactly, but possibly to those succeeding, and a tradition of early art as it came to be developed in the Church. Among these is one given on the authority of Fulgentius, a writer of the sixth century, in which at least are some suggestions towards our subject, although having a wide divergence from it in details. He says: The Romans made the images of Vain Honour in the manner of an inconstant woman, writing above her in golden letters, "This is the image of Vain Honour, look at her and always fly her." This image had a crown on its head, and a sceptre.in its left hand, and a peacock in the right, and was blind in the eyes and veiled, and seated upon a car drawn by four lions. And the meaning of these was, that whoever loves the vain honour of this world, is inconstant as an unsteady woman having a crown upon her head, because by the world, as by a king, she desires to be honoured. The sceptre in her hand is a sign that she always desires to command. Blindness in the eyes and with veiled face, because malice blinds her, so that she cares for no sin; whence the Book of Wisdom, "He blinded them by their malice." She has a peacock in one hand, for that as a peacock with its tail adorns its hinder part and front, but when it adorns its front it denudes its back, so such a one, adorning himself in the world, deprives himself of eternal glory. The four lions before her signify, that the four sins come with the vain honour of this world, namely Pride, Avarice, Luxury, and Envy.

Now in this description it is impossible not to see the analogy with the painting at Raunds. The subject is, indeed, substantially the same, for Vain Honour and Vain Glory are identical terms, and associated with it are the four principal vices. Moreover, we see other suggestions, such as the Crown and the Sceptre, signifying the vainglory of this world, and its desire to rule. ${ }^{x}$ It is to be noted that Fulgentius lived in a time, when there were two parties in the Church in fierce conflict with each other. The one, and that mostly in power, desirous to

1 It is also to be noted that the woman is mado blind. There is a peculiarity in the appearance of the eyes in the figure at Raund's which may have the samo intent. 
develop the ceremonial and decoration familiar to the temples of heathendom; the other section averse to this, as fearing from it the corruption of the simplicity of worship. The struggle continued long, and was saddened by the outrages of either side. There cannot be a doubt but, that from this time, we must trace the history of that art we call "Christian," and any relic of it, even in description, must be eagerly sought.

There is another work to which one must also refer as giving us some illustrations, and this is Spenser's "Fairy Queen." Spenser lived in an era of great development, when England was rapidly passing from the middle ages and its associations. Yet his poem shows abundantly where he had studied and enriched his mind. In the second Canto he describes the house of Pride; and Lucifera, whose name symbolises this vice, is associated with all the other deadly sins, forcibly painted, he often using the very words of the mediæval writers. In fact, in the whole poem there is no more noble passage than in this description of the House of Pride, and of Lucifera and her train. In one part she is thus described:-

"Lo! underneath her scornful feet, was lain A dreadful dragon with an hideous train, And in her hand she held a mirror bright, Wherein her face she often viewed feign."

Then she issues forth in her chariot, and strove to match, in royal rich array, "great Juno's golden chair":-

But this was drawn of six unequal Beasts, On which her six sage counsellors did ride,

Taught to obey their bestial behests,

With like conditions to their kinds appli'd;

Of which the first, that all the rest did guide,

Was sluggish Idleness the Nurse of sin;

Upon a slothful Ass he chose to ride,

Array'd in habit black and amirs thin,

Like to an holy Monk, the service to begin.

It is impossible not to see the analogy in these passages with descriptions previously given. It would almost seem like a satire on the Monkish life, written by a Reformer so to typify Sloth, had we nct read Cæsarius. But the whole passage, which occupies several stanzas, is rich in imagery, suggested or derived from medireval influences; and it is singularly interesting to trace these 
in the production of one of the greatest poets of the Augustan age of English literature.

But nothing is so complete or so full of meaning as the painting at Raunds. It is a combinatian of all that mediæval symbolism has arrayed upon the subject. Pride, in all the fulness of worldly honour and glory, is attired as a Queen. She has two sceptres, showing that she rules over the vices of the mind as those of the body, and they issue from her head and heart. But Death strikes her down, and Hell yawns beneath her feet.

The whole wall was to illustrate the moral, that how great soever man's estate upon this earth, death may overtake him in the midst of all; even in the sport which he is enjoying, or in the pursuits of pleasure or of selfindulgence. The next subject, therefore, continues the theme ; and we see three kings, richly attired, have issued from a castle to enjoy the pleasures of the chase or of hawking. They are attended by hounds, and carry hawks upon their wrists, when they are suddenly encountered by three grisly emaciated forms. These are three dead kings, who, in discourse, warn those living in their kingly honour "that such as they are now so shalt thou be." As this is by far the finest composition of this subject ever before discovered in this country, it would be most desirable could tracings from it be made, or at least good drawings, as a valuable record of our mediæval art, early in the fifteenth century, in case of their decay or future destruction.

The interest attending this example lies in its grand size, and the complete manner in which it is carried out. The figures are well proportioned and picturesquely composed, especially as regards the arrangement of the draperies. The first king, in the closely fitting jupon of the fourteenth and fifteenth century, has his ermined mantle thrown over one shoulder, thus shewing his entire figure as he turns towards the second king, who strides towards him, looking at the uncouth objects, that thus cross their path; this figure is also most picturesque. The third king, who is timidly advancing in the rear, has his mantle more closely wrapped around him. The whole group shows a very superior knowledge and artistic power to that usually seen in the ordinary paintings dis- 
covered in our churches, Some details are curious. In the rear of the last king, and in front of the castle, are two posts, through which a large chain has been drawn; but whether it belonged to the machinery of a drawbridge or not is not obvious. Rabbits or hares are visible on the ground by their feet. All the figures have scrolls, but none of the inscriptions are legible from below, but the character of all these is well known.

As one of the most popular of the subjects found in our churches, it merits attention, especially when treating of so fine an example. I shall have again to allude to it.

The north aisle contains remains of paintings from the legend of St. Katharine, and, originally, must have had eight subjects completely illustrating it. There are two dates to the paintings preserved; the earlier ones, and the best, are in monochrome, simple red outlines, and may be placed to the commencement of the fifteenth century. But the latter, though of the same subject, and overlying the earlier series, are executed in various colours after nature. They have not an equal merit with the earlier work, and from the broad-toed shoes belong to the early part of the sixteenth century. In some places these have been entirely removed in clearing off the whitewash, thus disclosing the older series.

The legend of St. Katharine of Alexandria is one of a class, evidently in high favour, illustrative of the early struggles of Christianity. Altars, dedicated to this saint, are found to have existed in some of the humblest of our parish churches. It is a strange story, altogether mythical, the chief tendency being to enforce what was called the "religious life," that is, monachism. It is proper, therefore, that we view it in its ancient spirit, and not in that of modern criticism. It is necessary to give an abstract of it, as we follow the description of the paintings preserved.

At the east end of the aisle, above and around the situation of the Altar, are traces of diaper work, but the illustrations of the story begin, and are continued, on the wall intervening between the windows of the north side. I do not doubt but that the first was that known as the "Marriage of St. Katharine," one which has exercised the art of many of the great masters, and is often found in 
our galleries. To explain it we must recount the legend. St. Katharine was of royal parentage, her father being King of Cyprus. The Emperor Maxentius summoned him, with many other of his vassals, to his court at Alexandria, whither he went with his wife and daughter; and whilst they sojourned in that city he took the opportunity of having Katharine instructed in all knowledge and science. She was of extreme beauty, and was eagerly sought in marriage; but the Emperor asked of her mother that she should espouse his son, and this she communicated to Katharine. But the young lady's reply to the proposal was, that she never would marry any man who was rot as noble, as prudent, as beautiful, and as rich as herself; and although the Emperor's son might be in nobility and riches equal to her, yet in knowledge and beauty he was a long way off. Thereupon her mother, much distressed, seeks advice, and it is thought, that her daughter should see a pious hermit, who questions her, and finding out her disposition addresses her thus :"Oh! beautiful young lady! if you will believe in Christ, you will have a spouse who incomparably excels thee in nobility, wisdom, and beauty." Katharine consents to his teaching, and he presents her with a picture of the Virgin Mary holding the Infant Jesus, enjoining her to pray that she would show her Son to her. She obeys, but ever the Child averts his face. On the Virgin Mother asking why, he answers, "Katharine is ignoble, foolish, poor and bare," and she is directed to go again for instruction to the holy man. This she does, and he converts her to the Christian faith. Returned home, when at night in bed, she had a vision of the Virgin with her Son approaching her joyfully. And now Katharine is pronounced fair and good, and wise and fairer in faith. From being as a crow, she is now white as a dove. The Virgin then takes her right hand and conveys it to her Son, who places upon her finger a ring of faith, and accepts her in perpetual espousals.

This, very much contracted, is the basis of this legend, but of this subject no traces remain, as the place wherein it would have been is occupied by a tablet. The next space, however, contains traces of both periods. Of the later time, there are but few remains, which consist 
chiefly of portions of an altar with candlesticks. Of the earlier work there are indications of a number of figures, and a Gothic structure in the background with trees, \&c. One of the figures has a triple crown, in front of whom long trumpets are being sounded, and before it is a female crowned and nimbed. There is also one in mitre, chasuble, \&c.

To explain this, one must continue the legend.

Now the Emperor commmanded all, both rich and poor, to assemble with animals and to sacrifice them to the gods, and the Christians were to do so on pain of death. St. Katharine, now eighteen years old, hearing the bellowing of oxen, the sounds of music, and the tumultuous singing of the people, issued forth signing herself with the cross, and found Christians, from the fear of death, sacrificing. Seeing this, she boldly walked towards the Emperor saying, "Salvation, O King, I offer to thee, if thou will recall thy mind from the gods ; " and she continued reasoning against his idolatry. The Emperor, astonished at her boldness, and admiring her beauty, told her that after the sacrifices he would give her an answer. She is led to the palace, and the Emperor comes and asks her name and parentage, and finally appoints a time for the subject to be discussed with the learned men of his realm.

We now pass to the next subject, and here the later one is best preserved, but shows traces of the earlier series at the foot, which makes us regret that it is not uncovered. Here is a seated figure of the Emperor with triple crown, beneath a canopy, on his throne holding a sceptre in his right hand, with the end resting on his left, his right leg crossed over the other. He has long hair and beard, is in yellow robes and red mantle, and a dog is by his feet. Before him stands a female figure in royal robes, crowned, St. Katharine, who is arguing with an array of doctors in red gowns and black caps, one of whom conspicuously places one finger to his thumb.

This is the continuation of the legend. The Emperor has here assembled fifty of his wisest men from all the provinces who are to confute St. Katharine, one of whom has asserted this to be very easy. But the Saint reasons of Christ's passion and resurrection and reduces them all 


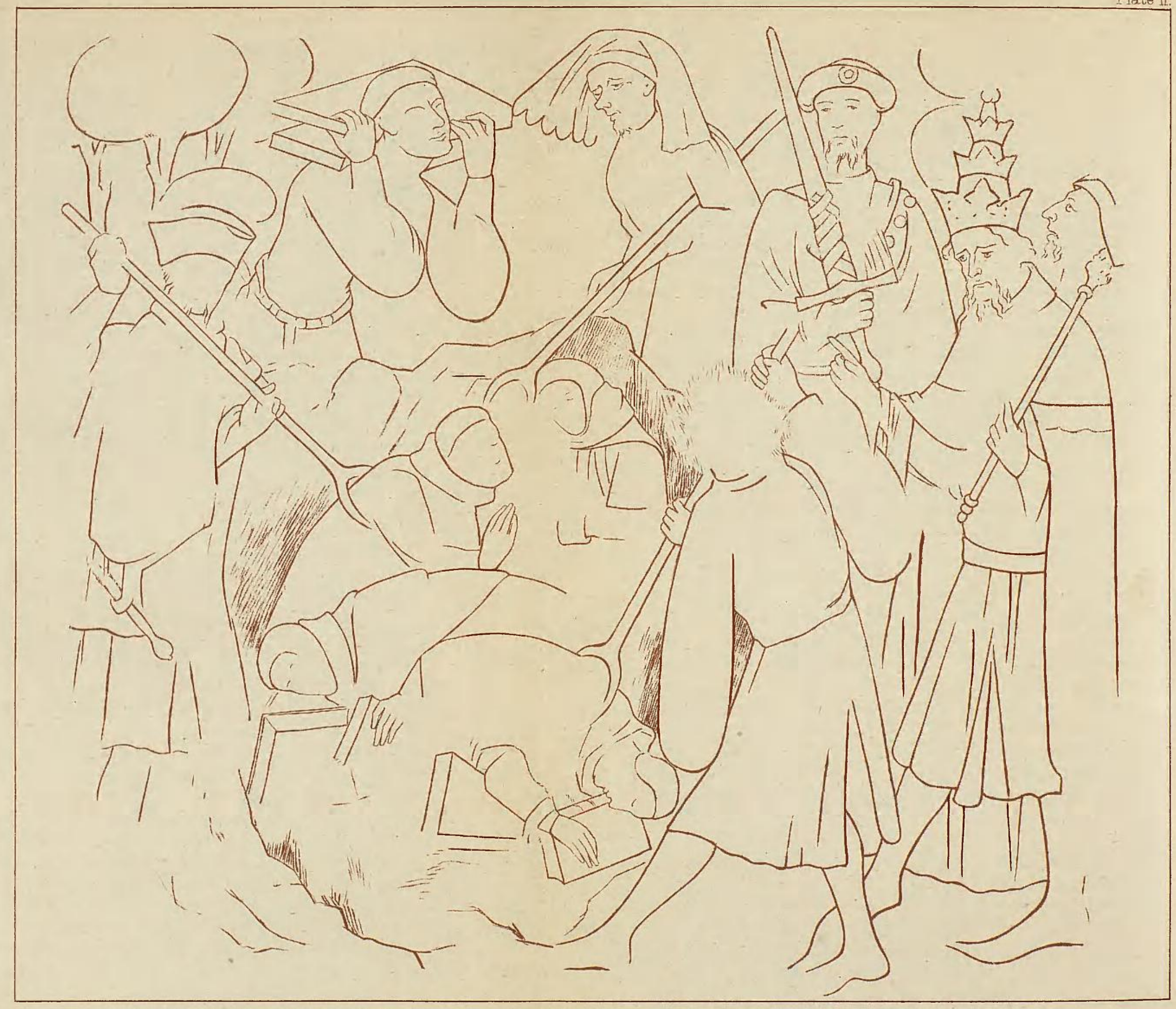

SCENE IN THE LIFE OF S? CATHERINE. WALL PAINTING IN RAUNDS GHURCH NORTHAMPTONSHIRE. 
to silence, at which the Emperor was exceeding wroth, but they told him that the spirit of God was in her, and finally, that she had converted them to the Christian faith. At which the tyrant, inflamed with fury, commanded that they should all be burnt in the midst of the city. But, fortified by the sign of the cross, they rendered their souls to God, and neither hair nor clothes were injured by the fire.

Now the last portion of the subject is illustrated by one of the earlier series, and that which is the most perfectly preserved; which is the more interesting, as it is exceedingly rarely found. There is a pit, into which a number of figures have been thrust by officials with pitch forks. Some hold books, and a figure laden with books is about to cast them in. By the side stands the Emperor in triple crown. and holding: a sceptre. He is giving orders. By his side stands his sword-bearer, the baldric wound about the uplifted sword, and he wears a kind of turban. The figures in the pit wear the cap or coif of doctors of law. (Plate II.)

Over the north door is the figure of St. George encountering the Dragon, but it is not a very complete rendering of the legend, allowance being made for its mutilated condition. It is executed in outline like the rest in this aisle and is of the same date. On the other side of this door the story of St. Katharine continues, with an illustration of the earlier series, but much more mutilated. It is nevertheless very curious. In the centre we see a castellated structure with embattlements and square towers at the angles. Through a large open window in this are seen the remains of the figures of St. Katharine crowned and nimbed, and on each side an angel, all very much defaced. In front, outside, is a crowned female figure kneeling, and by her side also kneeling we recognise by the turban like head-dress the sword bearer of the previous subject, i.e., the Porphyrius of the legend. There are other figures, one on the left of the castle wears on his head, a hat similar to that worn by the Papa of the Greek Church, and on the other side a female is approaching with the well known horned head dress. The legend will explain this in continuation.

The Empe ror then addressing the Saint in flattering: terms, tells her that after the Queen she shall be called

VOL. XXXIV. 
second in his palace, and her image should be placed in the city and be adored as a goddess. To which she answered. "Desist from speaking of such things, which are wicked to think of; I have delivered myself over as the Spouse of Christ, and not even torments shall make me recall." Then he, filled with fury, commanded her to be stripped and given up to be scourged, and to be taken to a dark ceil in prison, and there kept twelve days without meat or drink. The Emperor had occasion to depart to the confines of his realm on certain urgent affairs. In the meantime, the Queen. accompanied by the chief of the soldiers, went in the middle of the night to the prison, in which, when she entered, she saw an ineffable brightness shining, and angels anointing the virgin's wounds. Then Katharine began to preach of eternal glory to the Queen, and converted her to the faith, and predicted for her a crown of martyrdom, which when Porphyrius had heard he threw himself at the feet of the virgin, and together with two hundred soldiers received the faith.

The next space, where a subject would naturally have been continued, is entirely defaced, yet it is easy to say what would have occupied it. For it is a subject which specially belongs to this legend. The Emperor again endeavours to shake her constancy, and, failing, threatens her with torment. He commanded her to be put between four wheels having iron teeth, and the sharpest nails around them. These, moving in contrary directions, were to cut the virgin to pieces. Then she prayed to God that he would convert the people, and break the machine. Forthwith, an Angel of the Tord descended und struck the wheels with such force that the broken parts killed four thousand men.

The Queen then avows herself a Christian, and is put to death. Porphyrius does the same, and is beheaded, and his body given to dogs. Maxentius orders St. Katharine either to sacrifice to the Gods or to undergo decollation. She replies, "Do what you will with me, I am prepared to suffer." She was then led to execution, begging permission to pray, and finally said to the executioner, "Do as you ought," and she was beheaded.

The decollation, as above described, is represented by one of the later series, and is on the west wall. It 
shows the Saint kneeling, her hands conjoined in prayer, whilst the executioner, in slashed doublet, with one hand holds the maiden's hair, and in the other brandishes a large uplifted sword; a figure in yellow stands byperhaps, the Emperor.

The story is finally concluded by a painting which also belongs to the later time, on the other side of the west window, and shows a series of angels around a tomb. The execution is rather coarse. There is no difficulty in comprehending this subject, as the legend tells us that her body was conveyed by angels to Mount Sinai, and there honourably buried. The artists of the Renaissance often painted it, but perhaps none surpass the fresco by Luini, now preserved in the Brera at Milan. It is also given in the series in the Chapel of St. Sepulchre, of the Cathedral of Winchester, date thirteenth century. (Vide "Winchester Volume" of British Archæological Society.)

Uver the chancel arch, there are representations of angels kneeling and holding the several instruments of the Passion between the four arms of a cross, which probably was raised above the surface and highly decorated. But all this is in a very mutilated condition.

Over the arch which opens into the tower there are the remains of a painted clock face, shewn as being held by angels kneeling, behind which are figures of a man and his wife kneeling, with hands conjoined as in prayer. These are the donors, and an inscription beneath desires a prayer for their souls. The face of the clock is remarkable for having the twenty-four hours of the day inscribed upon it, which is perhaps an unique instance in England of this practice which still retains in Italy. The date of these latter belongs to the fifteenth century.

The village of Slapton, a primitive place, four miles from Towcester, though close to a railway, may still be said to be-

"Far from the madding crowd's ignoble strife."

Its church stands on the edge of a little knoll, and though small, has many interesting architectural details. It consists of nave and north aisle with norch forming the principal entrance, and a tower at the west end. It commends itself to Archæologists as, at present, it has not suffered restoration. It contains the original seats, pussibly 
as old as the oldest part of the church, which may be referred to the thirteenth century. The arch, separating the nave from chancel, is remarkably small, being under 6 feet in height, and not quite 4 feet in width. The side piers have both been perforated at a later date in order to make the altar more easily seen. The floor of the nave rises from the chancel arch towards the west end, and preserves some very good specimens of early tiles. The features here described are shown in the several examples given in Vol. iii of this Society's Journal (p. 297, et seq.)

Entering by the porch we perceive that the north aisle is divided from the nave by an arcade of three arches of unequal size. The largest of these is the central arch beneath which leads into the nave. In the spandrils which face us are traces of paintings. One is too much defaeed to give any clue to its subject, but the other is the Annunciation, having no particular features. Both figures are standing, and a scroll is between them, upon which has been inscribed, "Ave Maria, gratia plena." This is the only scriptural subject in the Church. As we proceed into the nave, on our right hand is a painting upon the voussoir of the arch. Its date is possibly at the commencement of the sixteenth century, and represents what is called "St. Gregory's Mass," or "St. Gregory's Pity," and is that subject which is intended to enforce the doctrine of transubstantiation. There is an altar, above which arising as trom a tomb appears the figure of Christ displaying the wounds of his passion, and the "bloody sweat," the left hand elevated, the right at his breast. Kneeling before him is a priest in the vestments of the Mass, and by his side is deposited the triple tiara.

The story is told in the Golden Legend. A certain woman brought bread to St. Gregory, and when in the mass he offered the body of the Lord and said, "The body of our Lord Jesus Christ keep thee to eternal life," she smiled. He then removing his right hand from her mouth replaced that part of the bread on the altar. After which lie asked her before the people why she laughed. Because, she replied, the bread which I have made with my own hands you call the Lord's body. Then Gregory put himself to prayer, and arising, found that particle of bread 
made flesh to the size of a finger, and thus the woman was brought back to the faith.

In art it is always represented as above described. It is rarely, if at all, found before the fifteenth century, but continued to be so treated until late in the sixteenth century, as by Albert Durer and others.

'The next arch, abutting on the tower, has a subject in a similar position on each side. One representing the ecstacy of St. Francis, is very common with the painter of every school. Here the Saint is kneeling before a crucifix upon a rock or mound, and scintillations issue from the wounds, as rays to his hands, feet and breast. Usually it is a Seraphim displayed as a cross, by which the stigmata are affected, and which is most in accord with the legend, which says that "in a vision of God the blessed Francis beheld a Seraphim as crucified, and so to him evidently impressed the signs of crucifixion that he appeared as if he himself was crucified."

The painting on the opposite side shows two persons, apparently male and female, who are carrying a beam between them. I do not know of any story which answers to this, and consider it to be merely a record of some benefaction to the structure of the church, as neither figures are nimbed.

On the north wall is conspicuously placed, nearly opposite to the chief entrance, as usual, the figure of St. Christopher, differing in no material points from the usual conventional treatment. It is in tolerable preservation, but shows in many places traces of an earlier figure beneath the present one. Amongst the details most worth remarking is the figure of a siren or mermaid in the river, who is combing her long locks by the aid of a mirror, which she holds in her hand. Westwards of this is a painting of our Lady of Pity. The Virgin is seated in a chair with the dead body of our Lord across her lap. It is not common to find this subject in England, but one of the finest works of the sculpture of the Renaissance is a Pieta, by Michael Angelo.

On the splayed jamb of a window close by is a figure in long tunic and mantle, seemingly holding a bag, but it is a good deal, defaced. The symbol is that given to 
St. Matthew, as having been a Publican, but one cannot say with certainty if this be truly attributed.

Turning now to the south wall, we find the familiar subject of St. George encountering the dragon, and it is as usual to find this on the south wall as that of St. Christopher on the north; and they are frequently, as in this instance, opposite each other. Here again are traces of a previous painting of the same subject, and, as it appears to me, the later artist has utilised portions of the earlier work. Some parts of the design are boldly designed and executed with some degree of skill, the figure of the dragon especially so. The features of this subject are so common, and offer little variety of treatment. St. George encountering the dragon, with his lance in rest; in the background a lady, royally crowned with a lamb in tether; a castle, from which look out a king and queen, is the usual treatment observed. The story is told in the Golden Legend, as follows:-

George, a tribune of the country of Cappadocia, arrived by a certain way, in the province of Libya, to a city called Silena, near to which city was a lake as big as a sea, in which a pestiferous dragon lay concealed, who oftentimes put to flight the people who armed themselves against him, and by his breath killed all those approaching to the walls of the city. On account of which, the citizens were compelled to give two sheep daily to him, that they might appease his fury; otherwise he so invaded the walls of the city, that many were slain. Now, when nearly all the sheep had gone, counsel was taken that each man by lot should give of his sons and daughters, and these had nearly all been consumed also. In this strait the king's daughter is taken by lot and adjudged to the dragon. Then the king in great grief says, "Take my gold and silver and the half of my kingdom, but send back my daughter lest she likewise dieth." To whom the people in fury replied, "Thou, O King, hast made the edict, and all our children are dead, and thou canst scarcely save thy daughter. Unless you comply, as in other cases you ordained, we will destroy thee and thy house." The king, then, weeping, took his daughter, and besought that he might have eight days of mourning previously to her being 
given up. The time having expired, he took his daughter, indued her with royal robes, saying, "Alas! I had thought to have invited princes to thy nuptials, to have adorned the palace with pearls, to hear drums and trumpets, but you go to be devoured by the dragon." Then she, throwing herself at his feet, asks his blessing; and with tears he leads her towards the lake. Then the blessed George, as he passed by, saw their mourning, and asked her what it meant. She answered, "Good youth, mount your horse and fly, lest with me you likewise perish." To whom he said, "I fear not, damsel, but tell me what this means, with all this crowd looking on." At length she related her story, again beseeching him to retire; but he replied he would in Christ's name help her. As they were discoursing the dragon raised his huge head from the lake. Then George mounting his horse, fortifying himself with the sign of the cross, boldly put his lance in rest and went to meet the dragon, grievously wounded him, and cast him to the ground. He then said to the damsel, "Cast your girdle about his neck, nothing doubting," which when she had done, he followed her like a dog.

This is as much of the legend as is illustrative of this subject, so commonly found in cur churches, and doubtless once universal in this country. That the story is like that of St. Christopher and many others, a parable to illustrate christian teaching in a familiar manner, one cannot doubt when it is well studied. The dragon is an old symbol of evil, and plays its part in numerous stories and christian legends, all tending to the same end. Here it is vanquished by the christian knight, that is, he conquers evil, fortified by the sign of the cross, the symbol of gospel truth. The legend of the Drachenfels on the Rhine (the Dragon's Rock) is exceeding pretty, having exactly the same tendency. It is the cross which saves and which conquers. So also in the story of St. Margaret and many others. To read it as a mere tale, the story of St. George may excite but little reverence; look upon it as we look upon the stories given to children, and as it was once addressed to minds scarcely more informed, and its teaching is beautiful. It is only when we would make it a real history, and analyze it as such, that we degrade it; 
because it would not then pass a critical analysis. As St. Christopher was addressed mostly to the common mind, as potent to aid in all the instant maladies and evils of this life, saving from fatigue or from sudden death, so St. George appealed to the knight or soldier, who was to succour the distressed and to be the scourge of evil. Such was the theory of chivalry.

Why St. George became the patron saint of England belongs to another history. It is stated that Robert Duke of Normandy, the father of William the Conqueror, fighting against the Saracens, saw St. George visibly on their side, giving them the victory over their enemies. Certain it is that the ancient war-cry of England, "God and St. George," appears nowhere before the Norman Conquest, and, most probably, not till some time after. It is easy to understand how, in this popular worship, the tradition of having given military aid made his figure an object of reverence, as the representative saint of the English knighthood. Spenser's Redcross knight is but the legitimate descendant from the ancient legend of St. George. Beneath the figure of St. George is the subject of "Weighing of Souls," which belongs to an earlier date, and it was partially, or wholly overlaid by the later work. The figure of St. Michael, holding the balance, is nearly obliterated, but on his left is a female figure in red mantle and blue tunic, holding in her left hand a little box and in her right a rosary, which she is laying upon one end of the beam. In one scale is a demon, in the other a small figure with hands enjoined as in prayer, representing the soul being weighed.

On a former occasion I gave a sketch of the history of this myth of "Soul weighing" as one of the most curious in the history of religion; and I alluded to the story here represented, but having forgotten my reference could not then give the original. I now supply the omission.

The story, speaking of a usurer, is as follows:-He, among all his vices, had one sole virtue, that he recited the Rosary of the Blessed Virgin Mary daily, as it had been taught by St. Dominic. At length, when near to death, he had a vision, in which he saw St. Michael the Archangel placing in one part of the scale all the good, 
which this man had sometimes done; and in the other part, he saw demons placing all his vices, which were infinitely greater and drawing down the balance. Who, deep in thought and astounded in consequence of the vision, presently beheld the Virgin to come nigh; and she, nearing the scale, in which his good doeds were reared up high in the air, placed her rosary upon it ; and immediately it began by its weight to fall and, by its sinking, to raise the scale on the opposite side. ${ }^{1} \quad$ The meaning of the $b o x$ most likely is intended to represent the good works or offerings made to her by the departed during his life. It is not without precedent.

On the south wall of the aisle, within the screen which encloses a chapel, are remains of paintings, here as elsewhere, of two periods. Figures of skeletons in a mutilated condition, which shows others beneath them, indicate the well-known morality to which I have before alluded. Some undecipherable inscriptions are beneath. Close by these, at the extreme east corner, there are traces of the earlier series. A figure of a bishop in chasuble, in front of whom is a youth in a fringed tunic and a cap upon his head, which shows the date to be early in the fifteenth century, and other fragments obscured by the overlying painting only suggest the possibility that it may relate to the legend of St. Nicholas, and it is a matter of regret, that it has been covered over so ruthlessly by the painter of the sixteenth century. The later subject shews a figure tied to a tree, and being shot at with arrows by archers in short tunics and broad-toed shoes. The familiar St. Sebastian, of our picture galleries, at once seems to come naturally as a solution. But we must bear in mind, that our churches were only decorated by the stories of such saints as were commonly known to us. Now St. Sebastian was not a saint worshipped in England. He specially belonged to the Peninsula, Italy and France, where the name is frequent enough in families. But in England we have no churches dedicated to St. Sebastian, nor are children baptised with his name-a sure test of the reverence in which a saint has been held. In some parts of England there are saints localised, churches are dedicated to them there, and

1 Quoted in Molanus De Historia SS. Imagimum, \&e., \&e., Lovanii, 1771.

VOL, XXXIV. 
scarcely anywhere else; but others are common to Christendom, and are found everywhere. The same principle obtains in every country:

In the eastern counties the saint of most honour was Edmund, King of the East Angles, martyred by the Danes in 870 in the woods of Hoxne, near the Waveney, which separates the counties of Norfolk and Suffolk. He was bound to a tree and shot to death with arrows, and the homage to his memory extended as far inland as Northamptonshire. We must therefore rather ascribe this representation to him than to St. Sebastian, for the latter could scarcely have been introduced into an English village except through some foreign influence. I have therefore no doubt, that this represents the martyrdom of the Anglo-Saxon King, Edmund, one of the most celebrated of English saints, and about whom legends still exist in the village near which he met his death.' His body was for a long time sheltered in a little oratory of wood near Ongar. in Essex ; and there can be little doubt that this now forms a portion of the church of Greenstead. Lidgate, a monk of the Abbey of Bury St. Edmunds, where his shrine was, elaborated the story of his life, and the richly illuminated MS., which he presented to Henry VI, is now preserved in the British Museum. Beneath one corner of this painting, there also appears part of the subject of St. Anne teaching the Virgin. It is interesting to note, that the character of the painting of the sixteenth century, in both these churches, is so identical in style of execution, that, it is extremely probable, the same hand did both. The monkartist, for such, doubtless, he was, paid little respect to what had gone before, and the new style, being more showy in its colouring, was evidently preferred. And it was painted over the older work without any preparation,

\footnotetext{
'At one end of the village is a brook crossed by a little wooden foot-bridge ealled Goldbridge. It is said that under this bridye, for there is another not far off, King Edmund concealed himself from his pursuers. But a bridal party returning hon'e by moonlight, the bride saw his golden spurs glitter in the reflection of the stream, and her exclamation lea to his discovery. 'T'he king then pronounced a curse on all
}

who should afterwards cross that bridge on their way to or from marriage. The common people (at least eighty years ago) always avoided the bridge on such occasions, and would rather go miles round than run the hazard of the curse falling upon them. So relates a lady now ninety six years of age, born in this village, as one of the memories of her youth. 
a slovenly proceeding, which has its reward in being less durable, and yielding with the removal of the whitewash. There is a coarse diaper, done in black, showing a duck swimming, \&c., perhaps some heraldic cognisance, which appear in many parts of the walls, and must be later than any other part of the painting. It is unimportant, and cannot be well understood in its mutilated condition. Altogether, the numerous objects here described, mutilated as they are, teach us a good many facts towards a general history of the painting in our mediæval churches. 